\title{
NILAI-NILAI MORAL MASYARAKAT SUNDA (KAJIAN NASKAH SEWAKA DARMA DI SITUS KABUYUTAN CIBURUY GARUT)
}

\author{
Baharudin \\ 1,2,3 Program Studi Pendidikan Sejarah, Universitas Galuh, Jl. R. E. Martadinata No.150, Ciamis, Indonesia \\ Email: b4h4rudin1001@gmail.com
}

\begin{abstract}
The Sewaka Darma manuscript is an ancient Sundanese text written using ancient Sundanese letters and language, written on palm leaves and scraped by using peso pengot. The use of media in making manuscripts shows that the manuscript is classified into traditional historiography. To find outthe values contained in the Sewaka Darma text, the method used in this study is the historical method including Heuristics, Criticism, Interpretation, and Historiography. The form of Sewaka Darma is kawih (advice) about wisdom and moral messages taught at that time. The text of Sewaka Darma contains moral values and religious character values, honesty, simplicity, creativity, loving the motherland, politeness and wisdom. The message contained in the manuscript can also be used as research material of moral message for today's society.
\end{abstract}

Keywords: Moral Values, Sewaka Darma, Sundanese Manuscripts

\begin{abstract}
ABSTRAK
Naskah Sewaka Darma merupakan naskah Sunda kuno yang ditulis menggunakan huruf dan bahasa Sunda kuno, ditulis di atas daun lontar dengan cara digores menggunakan peso pengot. Penggunaan media dalam pembuatan naskah menunjukan bahwa naskah tersebut tergolong kedalam historiografi tradisional. Untuk mengetahui bagaimana nilai-nilai yang terkandung dalam naskah Sewaka Darma tersebut, maka metode penelitian ini menggunakan metode sejarah yang meliputi Heuristik, Kritik, Interpretasi, dan Historiografi. Bentuk Sewaka Darma merupakan kawih (nasihat dan petuah) tentang kebijaksanaan dan pesan-pesan moral yang diajarkan pada masa itu. Naskah Sewaka Darma mengandung nilai moral dan nilai karakter religius, kejujuran, kesederhanaan, kreatifitas, cinta tanah air, sopan santun serta bijaksana. Pesan yang terdapat dalam naskah juga bisa dijadikan sebagai bahan kajian mengenai pesan moral dimasyarakat saat ini.
\end{abstract}

Kata kunci : Nilai Moral, Sewaka Darma, Naskah Sunda

Cara sitasi: Baharudin. (2020). Nilai-Nilai Moral Masyarakat Sunda (Kajian Naskah Sewaka Darma Di Situs Kabuyutan Ciburuy Garut). J-KIP (Jurnal Keguruan dan IImu Pendidikan) , 1 (2), 41-46. 


\section{PENDAHULUAN}

Moral berkaitan dengan akhlak, budi pekerti, dan ajaran kesusilaan. Sasaran dari moral adalah keselarasan dari perbuatan manusia dengan aturan-aturan yang mengenai perbuatanperbuatan manusia itu (Salam, 2000). Nilai moral penting bagi kehidupan umat manusia, baik sebagai makhluk pribadi, makhluk Tuhan, maupun makhluk sosial. Dalam kenyataannya perilaku masyarakat bersifat dinamis, selalu bergerak ke arah perubahan. Menurut Suratman (2010). Perubahan sosial yang saat ini terjadi dalam kehidupan masyarakat adalah modernisasi.

Pada era globalisasi ini di mana perkembangan telekomunikasi dan informasi mampu tersebar luas yang dapat diakses dengan sangat mudah, hal ini menyebabkan berbagai nilai-nilai dari luar yang negatif tidak lagi dapat disaring sehingga dengan mudah mempengaruhi pemikiran dan karakter generasi (generasi masa kini) sehingga menimbulkan kekhawatiran terhadap pengikisan jatidiri yang terkait merosotnya penghayatan nilai-nilai keagamaan, nasionalisme, nilai sosial budaya bangsa dan perkembangan moralitas individu.

Menurut Koesoema (2007) Penyimpangan Perilaku remaja dapat diakibatkan oleh faktor berikut ; pertama, longgarnya pegangan terhadap agama, disaat sudah menjadi tradisi bahwa segala sesuatu dapat dicapai dengan ilmu pengetahuan. Kedua, derasnya arus budaya matrealistis, hedonistis dan sekularistis. Ketiga, kurang efektifnya pembinaan moral yang dilakukan oleh keluarga, sekolah, maupun masyarakat. Pembinaan moral anak selama ini banyak dilakukan dengan cara menyuruh anak menghafalkan rumusan tentang baik dan buruk, sehingga anak akan dibesarkan tanpa mengenal moral itu, bukan dengan dibiasakan menanamkan sikap yang dianggap baik untuk menumbuhkan moral anak.

Pendidikan moral bukanlah hal yang baru dalam menata segala tindak dan prilaku seseorang. Padahal apabila setiap budaya bangsa yang terbentuk diwariskan secara benar tentu akan secara langsung memberikan bimbingan terhadap nilai-nilai moral kehidupan. Salah satu contoh adalah kebudayaan dikalangan masyarakat sunda yang memberikan tuntutunan dalam berprilaku harus senantiasa bermoral. Hal ini tidak saja tercermin secara turun temurun melalui generasi melainkan tersurat dalam berbagai media hasil kebudayaan seperti yang tersurat dalam naskah Kuno warisan budaya sunda bernama Naskah Sewaka Darma.

Di Indonesia masalah kenakalan yang dilakukan oleh para remaja sudah mencapai tingkat yang cukup meresahkan bagi masyarakat. Seperti yang sering terlihat di pemberitaan media masa, kasus-kasus yang melibatkan para remaja, seperti tawuran, terlibat kasus narkoba, seks bebas dan lain-lain. Tindak kenakalan yang dilakukan oleh para remaja dalam studi masalah sosial dapat dikategorikan kedalam perilaku menyimpang. Dalam perspektif perilaku menyimpang masalah sosial terjadi karena terdapat penyimpangan perilaku dari berbagai aturan-aturan sosial ataupun dari nilai dan norma sosial yang berlaku. Perilaku menyimpang dapat dianggap sebagai sumber masalah karena dapat membahayakan tegaknya sistem sosial.

Berkaitan dengan hal tersebut, naskah Sewaka Darma memiliki nilai-nilai moral yang bisa dijadikan sebagai pembelajaran dalam menangani masalah moral dikalangan remaja khususnya umumnya disemua kalangan. Oleh karena itu, peneliti membuat rumusan masalah untuk mengkajinya. Rumusan masalah tersebut adalah: 1) Bagaimana gambaran dari naskah Sewaka Darma? 2) Bagaimana Nilai-nilai moral yang terkandung dalam naskah Sewaka Darma?

\section{METODE PENELITIAN}

Motede yang digunakan dalam penelitian ini adalah metode sejarah. Metode sejarah adalah suatu usaha untuk mempelajari dan mengenali fak-fakta serta menyusun simpulan mengenai peristiwa masa lalu. Tujuannya adalah untuk membuat rekontruksi masa lalu secara sistematis dan objektif. Dalam tataran praktisnya metode sejarah dilaksanakan dalam empat langkah, yaitu: (1) Heuristik, (2) kritik, (3) interpretasi, (4) historiografi. 
Heuristik, ialah tahapan metode sejarah yang pertama yang dilakukan, heuristik ialah proses mengumpulkan sumber-sumber yang relefan dengan permasalahan penelitian. Dalam kritik ada dua macam hal yang harus kita lakukan: autentisitas atau keaslian sumber atau kritik ekstern. Dan kredibilitas, atau kebiasaan dipercayai atau kritik intern (Kuntowijoyo, 2013). Interpretasi adalah menafsirkan keterangan dari sumber-sumber sejarah berupa fakta yang terkumpul dengan cara merangkai dan menghubungkan sehingga terciptanya penafsiran sumber sejarah yang relevan dengan permasalahan penelitian. Historiografi merupakan sebuah proses yang dilakukan setelah sumber-sumber sejarah yang telah ditemukan dan dikumpulkan, diverifikasi, kemudian selesai dianalisis dan ditafsirkan.

Sebuah penelitian bisa dikatakan ilmiah apabila memenuhi syarat-syarat keilmuan. Namun selain itu, penyajian suatu karya ilmiah juga harus memperhatikan tata dan susunan bahasa. Penulis berupaya untuk menyusun penelitian ini dengan melakukan analisis secara menyeluruh terhadap berbagai aspek yang berkaitan dengan nilai-nilai moral masyrakat Sunda dalam najian askah Sewaka Darma.

\section{HASIL DAN PEMBAHASAN}

\section{Gambaran Naskah Sewaka Darma Dalam penulisan naskah Sunda}

Kuno ada beberapa media yang menjadi bahan tulisannya. Keseluruhannya memang menggunakan media-media alam seperti misalnya dari Batu, Daun Lontar, Daun Gebang (Nipah), Kalapa, Kawung, Bambu, dan atau Daluwang (Kulit Tangkal Saeh). Naskah sunda Kuno yang medianya dari daun lontar adalah naskah yang ditulis di atas daun Lontar. Tulisanna diberi Carik dan ditulis dengan menggunakan peso pangot (pengutik) dengan cara digoreskan. Naskah dari daun lontar ini bukanlah sebuah naskah yang ditulis untuk kalangan elit (lain pikabuyuteun) melainkan bagi pembaca (atau pendengar) sebagai sarana mempelajari dan memperoleh ilmu atau kebijaksanaan. Tujuan dari pembuatan naskah-naskah sunda kuno ini mempengaruhi isi dari naskah-naskah itu. Misalnya, naskah yang menggunakan media daun lontar biasanya berbentuk puisi atau prosa yang pola metrumnya berkaitan dengan carita pantun (tradisi lisan sunda dimasa lalu). Artinya tradisi lisan ini mulai direkam dalam sebuah tulisan dan ditujukan kembali kepada masyarakat (non kabuyutan). Konsekuensi lain, naskah yang ditulis dalam media daun lontar, sangat dimungkinkan untuk dibacakan atau ditampilkan dalam pertunjukan (tradisi lisan) carita pantun. Sedangkan naskah-naskah sunda kuno yang menggunakan media Nipah atau Daun Gebang hampir semuanya berbentuk prosa didaktis dan berisi risalah-rissalah atau ajaran keagamaan. Bahasa yang digunakan pun bahasa Jawa Kuno. Bentuk ini tentunya tidak ditujukan kepada masyarakat umum, tetapi ditujukan untuk masyarakat dilingkungan Kabuyutan.

Naskah Sewaka Darma sendiri ditulis menggunakan huruf dan bahasa Sunda Kuno, ditulis di atas daun lontar dengan cara digores menggunakan peso pengot. Dilihat dari terminologinya, Sewaka diartikan sebagai "pengabdian", jadi Sewaka Darma adalah pengabdian kepada Darma. Naskah Sewaka Darma juga disebut dengan Kropak 408. Naskah ini merupakan milik Museum Nasional Jakarta. Jumlah halamannya ada 37 buah (74 halaman), namun yang bertulisan hanya 67 halaman. Bentuk huruf dalam naskah ini adalah huruf Sunda periode akhir. Naskah Sewaka Darma terdiri atas empat kropak (4 naskah paralel), naskah pertama yang diterjemahkan oleh Danasasmita (1987) dengan judul Sewaka Darma, Sangyang Siksa Kandang Karesian, Amanat Galunggung, Transkripsi dan Terjemahan.

Naskah kedua menjadi bagian naskah Ciburuy I, naskah ketiga berada dalam peti 2, dan naskah keempat tersimpan dalam peti 3 koleksi kabuyutan Ciburuy, Garut. Secara garis besar, naskah ini berisi tentang uraian kaleupasan (moksa) yang menekankan kepada penggunaan tenaga, ucapan, dan tekad yang sesuai dengan tuntutan dan petunjuk darma. Naskah Sewaka Darma disusun dengan tujuan pembaca masyarakat umum (pada zamannya). Hal ini bisa dari bahan atau media yang 
digunakan dalam penulisan naskah ini, yakni terbuat dari daun lontar yang cara penulisannya digores menggunakan peso pangot.

Dengan mengacu pada penjelasan sebelumya, Sewaka Darma diperuntukkan untuk kalangan non kabuyutan atau masyarakat umum (pada masa itu). Hal ini sesuai dengan isinya yang diutarakan dalam bentuk puisi berlarik seperti Carita Sunda. Kesesuaian ini berlanjut pada bentuk aksara dan bahasa yang digunakan. Naskah Sewaka Darma merupakan naskah yang dibuat pada masa kebudayaan hindu-Budha dan masih dihayati di tanah pasundan (Jawa Barat) khususnya. Dari segi bahasa dan aksara yang digunakan, naskah Sewaka Darma menggunakan aksara Sunda Kuno. Menilik aksaranya, Sewaka Darma ditafsirkan atau diperkirakan berasal atau di tulis pada abad ke 14 (seperti halnya Prasasti astana Gede-Kawali).

Hal di atas menjadi catatan awal untuk melihat naskah Sewaka Darma dalam menjelaskan ajaran kebijaksanaannya yang bisa dipilah dalam dua bagian besar. Pertama, isinya tentang tokoh utama: Sang Sewaka Darma sebagai murid yang menerima berbagai wejangan dan moral dari gurunya (yang dinamakan pandita, mahapandita, dewatakaki, sang Nugraha). Sang Sewaka Darma mendapatkan nasihat supaya dapat terhindar dari segala godaan yang tidak sesuai dengan norma kehidupan. Sang tokoh belajar membedakan perbuatan- perbuatan yang baik dan yang tidak baik. Contoh tindakan tidak baik di dalamnya adalah berdusta, membunuh, menuntut yang tidak berdosa, mengguna-gunai, dan sebagainya. Tindakan baik, misalnya, adalah melakukan dasasila dan pancasaksi (Siswantara, 2015).

Menurut Siswantara (2015), hal-hal yang berkaitan dengan ajaran moralitas yang disampaikan Sewaka Darma adalah sebagai berikut: Pertama, Dunia Sakala adalah dunia nyata sebagaimana kita saat ini. Dunia ini diisi atau ditempati oleh makhluk hidup: manusia, hewan, dan tumbuhan. Mereka (yang hidup di alam sakala) ini terdiri dari dua unsur: badan fisik dan badan nonfisik (rohani). Kedua, dunia Niskala adalah dunia gaib atau roh sebagaimana kita pahami. Dunia ini diisi atau ditempati oleh makhluk gaib: roh manusia, dewa dewi, hantu (istilah awamnya), syanu (roh netral). Ketiga, dunia Jatiniskala adalah dunia maha gaib nan sempurna tempat zat Yang Maha Tunggal, sang Hyang Manon, Yang Maha Pencipta, Si ljunajati Nistemen, pencipta batas tetapi tak terkena batas. Dunia ada dalam zatnya.

\section{Nilai-Nilai Moral yang Terkandung dalam naskah Sewaka Darma.}

Berbicara tentang moralitas, orang sunda seringkali mendapatkan pengajaran tentang keharusan moral manusia sunda. Banyak sekali ajaran, mulai dari ungkapan, peribahasa, carita pantun, bahkan ampai naskah sunda kuno yang isinya tentang permasalahan etika atau moral. sebagai contoh sebuah ungkapan: "Mipir bukit palasari, tanjakan maraga cinta. Sundana; apik ka ati, nyaah ka tanaga, udaran cangreud tina beuheung, tina cangreud loba biheung, jeung sasama silih papatahan silih pikaheman, nu matak sok pedar jodo panjang duriat, jodo meunang jodo, jadi opat modalna kasukaan, jadi kalimana".

Dalam tradisi masyarakat sunda, prinsip-prinsip etika terkandung dalam pandangan hidupnya yang tercermin baik itu dari tradisi lisan maupun tradisi tulisan. Tradisi itu bisa tercermin salah satunya dari peribahasa. Dari peribahasa setidaknya pandangan hidup masyarakat sunda terkelmpokan kedalam lima hal:

a. Pandangan hidup manusia sebagai pribadi;

b. Pandangan hidup tentang hubungan manusia dengan masyarakat;

c. Pandangan hidup tentang hubungan manusia dengan alam;

d. Pandangan hidup tentang hubungan manusia dengan Tuhan atau Sang Hyang;

e. Pandangan hidup tentang manusia dalam mengejar kemajuan lahiriah dan kepuasan batiniah.

Kelima hal itu, juga merupakan prinsip moral/etika bagi masyarakat sunda. Pertama, orang sunda berpandangan bahwa manusia harus punya tujuan hidup yang baik, dan senantiasanya sadar bahwa dirinya hanya bagian kecil dari alam semesta. Lebih rinci nilai-nilai moral yang terkandung 
dalam naskah Sewaka Darma adalah sebagai berikut: Pertama, Religius sesuai dengan ungkapan naskah:

"Anaking Mulah mo yatna-yatna, reungeu sabda sang pandita ingetkeun hayua lali, teher nging ngeunak-ngunak rasa ngarana ngapakeun tali, Ingeutkeun na dasa sila iseuskeun na panca sakit iyan ta ningkah keun raga mayahkeun sarira ngaleukaskeun suku tangan"

Ungkapan diatas merupakan pembuka dari naska Sewaka Darma yang menggambarkan tentang nasihat dari seorang guru kepada muridnya. Sang guru mengatakan "ingatlah dalam dasa sila, perhatikan dalam panca sakti", maksud dasa sila adalah 10 larangan atau ajaran yang menjadi sendi ajaran Budisme. Lima yang pertama disebut panca siksa yaitu larangan: berbohong, mabuk, berzina, mencuri dan membunuh bagi semua umat Budha. Lima yang terakhir berupa larangan tentang kenikmatan ragawi berlaku hanya bagi golongan pendeta. Adapun yang dimaksud dengan panca sakit adalah 5 macam penyakit yaitu: loba (serakah), moha (kebodohan), dosa (kejahatan), mana (takabur), udaca (keangkuhan) (Danasasmita, 1987). Kedua, jujur;

"Manguni salah na sabda lamun sabda te tuhu lamun lain sabda jati lamunna hamo rahayu lamun tiis bawana eta nu disalahkeun nu maka papa kalesa sanyarah na angen-angen"

Selain nilai moral dalam naskah Sewaka Darma juga terdapat nilai-nilai karakter seperti, Berani ditunjukan dengan kalimat berikut:

"Anaking mulah sya dekaja jamuga kena ti dinya sangkanna suka-duka mula(h) (hala) lawan hayu wwat pati lawan hirup ta(ng)kal sorga lawan papa"

Sikap kreatif, cinta tanah air, sopan santun serta sikap bijaksana.

\section{KESIMPULAN}

Naskah Sewaka Darma merupakan naskah Sunda kuno yang ditulis menggunakan huruf dan bahasa Sunda Kuno, ditulis di atas daun lontar dengan cara digores menggunakan peso pengot. Dilihat dari terminologinya, Sewaka diartikan sebagai "pengabdian", jadi Sewaka Darma adalah pengabdian kepada Darma. Naskah Sewaka Darma disusun dengan tujuan pembaca masyarakat umum (pada zamannya). Adapun penulisnya mengacu pada bagian naskah halaman terkahir adalah Buyut Ni Dawit, Buyut disini berarti cicit dari Ni Dawit yang tidak diketahui namanya.

Naskah Sewaka Darma ini secara keseluruhan menggambarkan tentang perilaku dalam kehidupan serta kesiapan diri atau jiwa dalam menghadapi maut. Namun secara rinci naskah Sewaka Darma ini juga mengajarkan nilai-nilai moral dan nilai-nilai karakter diantaranya religius, jujur, berani, sederhana, kreatif, cinta terhadap tanah air, sopan santun serta memiliki sikap bijaksana.

\section{REKOMENDASI}

Penelitian selanjutnya dapat lebih berupaya untuk menyusun penelitian dengan melakukan analisis secara menyeluruh terhadap berbagai aspek yang berkaitan dengan nilai-nilai moral masyrakat Sunda dalam najian naskah Sewaka Darma.

\section{UCAPAN TERIMAKASIH}

Ucapan terima kasih ditujukan untuk Program Studi Pendidikan Sejarah, Fakultas Keguruan dan IImu Pendidikan Universitas Galuh yang telah mendukung penelitian ini.

\section{DAFTAR PUSTAKA}

Danasasmita, S. (1987). Sewaka Darma, Sanghyang Siksakandang Karesian, Amanat Galunggung. Bandung: Bagian Proyek Penelitian dan Pengkajian Kebudayaan Sunda (Sundanologi), Direktorat Jenderal Kebudayaan, Departemen Pendidikan dan Kebudayaan.

Koesoema, D, A. (2007), Pendidikan Karakter, Strategi Mendidik Anak di Zaman Global. Jakarta: Grasindo. 
Kuntowijoyo. (2013). Pengantar Ilmu Sejarah. Yoyakarta: Tiara Wacana.

Salam, B. (2000). Etika Individual Pola Dasar Filsafat Moral. Jakarta: Rineka Cipta.

Siswantara, Y. (2015). Keutamaan Kritik Teks Atas Naskah Sewaka Darma. Laporan Penelitian Lembaga Penelitian dan Pengabdian Masyarakat. Bandung: Universitas Katolik Parahyangan.

Suratman. (2010). Ilmu Sosial dan Budaya Dasar. Malang: Intimedia. 